\title{
Episodic Precipitation of Wolframite during An Orogen: The Echassières District, Variscan Belt of France
}

\author{
Loïs Monnier ${ }^{1}$, Jérémie Melleton ${ }^{2}\left(\mathbb{D}\right.$, Olivier Vanderhaeghe ${ }^{1} \mathbb{D}$, Stefano Salvi ${ }^{1, *} \mathbb{C}$, Philippe Lach ${ }^{2}$, \\ Olivier Bruguier ${ }^{3}$, Anissa Benmammar ${ }^{1,4}$, Laurent Bailly ${ }^{2}$, Didier Béziat ${ }^{1}$ and Eric Gloaguen ${ }^{2,5}$
}

Citation: Monnier, L.; Melleton, J.; Vanderhaeghe, O.; Salvi, S.; Lach, P.; Bruguier, O.; Benmammar, A.; Bailly, L.; Béziat, D.; Gloaguen, E. Episodic Precipitation of Wolframite during An Orogen: The Echassières District, Variscan Belt of France. Minerals 2021, 11, 923. https://doi.org/10.3390/ $\min 11090923$

Academic Editors: Huan Li,

Rongqing Zhang, Jie-Hua Yang and Jingya Cao

Received: 6 July 2021

Accepted: 22 August 2021

Published: 26 August 2021

Publisher's Note: MDPI stays neutral with regard to jurisdictional claims in published maps and institutional affiliations.

Copyright: (c) 2021 by the authors. Licensee MDPI, Basel, Switzerland. This article is an open access article distributed under the terms and conditions of the Creative Commons Attribution (CC BY) license (https:// creativecommons.org/licenses/by/ $4.0 /)$.
1 Géosciences Environnement Toulouse, University of Toulouse, CNES, CNRS, IRD, UPS, 31400 Toulouse, France; loismonnier@yahoo.fr (L.M.); olivier.vanderhaeghe@get.omp.eu (O.V.); benmammar.anissa@gmail.com (A.B.); didier.beziat@get.omp.eu (D.B.)

2 Bureau de Recherches Géologiques et Minières, 45000 Orléans, France; j.melleton@brgm.fr (J.M.); p.lach@brgm.fr (P.L.); 1.bailly@brgm.fr (L.B.); e.gloaguen@brgm.fr (E.G.)

3 Géosciences Montpellier, University of Montpellier, 34000 Montpellier, France; olivier.bruguier@gm.univ-montp2.fr

4 Department of Geology, University of Science and Technology Houari Boumediene, Algiers 16111, Algeria

5 Institut des Sciences de la Terre d'Orléans, University of Orléans, 45071 Orléans, France

* Correspondence: stefano.salvi@get.omp.eu

\begin{abstract}
Monazite and rutile occurring in hydrothermally altered $\mathrm{W}$ mineralizations, in the Echassières district of the French Massif Central (FMC), were dated by U-Pb isotopic systematics using in-situ Laser ablation-inductively coupled plasma-quadrupole mass spectrometry (LA-ICP-MS). The resulting dates record superimposed evidence for multiple percolation of mineralizing fluids in the same area. Cross-referencing these ages with cross-cutting relationships and published geochronological data reveals a long history of more than $50 \mathrm{Ma}$ of $\mathrm{W}$ mineralization in the district. These data, integrated in the context of the Variscan belt evolution and compared to other major $\mathrm{W}$ provinces in the world, point to an original geodynamic-metallogenic scenario. The formation, probably during the Devonian, of a quartz-vein stockwork (1st generation of wolframite, called wolframite " $a$ "; $>360 \mathrm{Ma}$ ) of porphyry magmatic arc affinity is analogous to the Sn-W belts of the Andes and the Nanling range in China. This stockwork was affected by Barrovian metamorphism, induced by tectonic accretion and crustal thickening, during the middle Carboniferous (360 to $350 \mathrm{Ma}$ ). Intrusion of a concealed post-collisional peraluminous Visean granite, at $333 \mathrm{Ma}$, was closely followed by precipitation of a second generation of wolframite (termed " $b$ "), from greisen fluids in the stockwork and host schist. This $\mathrm{W}$-fertile magmatic episode has been widely recorded in the Variscan belt of central Europe, e.g. in the Erzgebirge, but with a time lag of 10-15 Ma. During orogenic collapse, a third magmatic episode was characterized by the intrusion of numerous rare-metal granites (RMG), which crystallized at $310 \mathrm{Ma}$ in the FMC and in Iberia. One of these, the Beauvoir granite in the Echassières district, led to the formation of the wolframite " $c$ " generation during greisen alteration.
\end{abstract}

Keywords: monazite and rutile dating; LA-ICP-MS; wolframite; Variscan belt; tungsten fertility; orogenic magmatism

\section{Introduction}

Some of the most important ore deposits in the world form due to successive magmatic/hydrothermal episodes, each playing a role in concentrating the metals (e.g., $\mathrm{Cu}, \mathrm{Au}$, REE [1-3]). Current genetic models for economic W deposition proposed in the literature invoke an early pre-enrichment during differentiation of a granitic magma followed by metal redistribution by related orthomagmatic fluids, resulting in wolframite and/or scheelite mineralization more or less proximal to the intrusive body (e.g., [4,5]). Recently, polyphased W-Sn deposits in the Nanling range (southern China) have been shown to grow during two clearly distinct magmatic/hydrothermal events, occurring at 220 and 150 Ma [6,7], 
suggesting that this could be the case for other $\mathrm{W}$ deposits and that the genetic models for their formation is potentially more complex than previously implied.

Indeed, $\mathrm{W}$ mineralization occurs in a wide diversity of magmatic/hydrothermal environments [8,9] and contrasting tectonic settings $[10,11]$, both favoring multiple ore generations. In this contribution, based on new geochronological data and on a review of the literature, we show that wolframite $\left[(\mathrm{Fe}, \mathrm{Mn}) \mathrm{WO}_{4}\right]$ mineralization in the Echassières district of the French Central Massif (FMC) is linked to three different magmatic bodies that were emplaced at different stages during the evolution of the Variscan orogen, similarly to the polyphased deposits of the Nanling range. Furthermore, combining these chronological data with mineralogical observations, we compare the mineralization of the Echassières district with analogous deposits elsewhere in the world in order to discuss how tectonic events marking major orogenic transitions control the occurrence and form of $\mathrm{W}$ deposits.

\section{Geological Setting}

The Variscan orogeny (Figure 1) results from closure of several oceans during the Paleozoic, separating micro-continents and the Gondwana and Laurussia landmasses [12]. The FMC is part of the internal zone of the Variscan belt that exposes a complexly deformed nappe pile [13-18]. Late Devonian HP relics attest to the deep burial and exhumation of oceanic and continental units during an early stage of tectonic accretion to the south of the Armorica continental ribbon [19-22]. Early to middle Carboniferous pervasive MP/MT Barovian metamorphism has been attributed to the transition from continental subduction to collision $[22,23]$ and the late Carboniferous exhumation of large migmatite domes associated with LP/HT metamorphism is considered to represent the gravitational collapse of the Variscan belt [24-27]. The evolution of the Variscan belt is marked by the intrusion and emplacement of a variety of magmas reflecting (i) the transition from an active margin with back-arc basins from the Devonian to the early Carboniferous and (ii) protracted partial melting of orogenic root coeval with the input of mantle-derived magmas from the middle Carboniferous to the Permian [28-34].

Located in the northern part of the FMC, the Echassières district $(\mathrm{Sn}, \mathrm{W}, \mathrm{Li}, \mathrm{Nb}-\mathrm{Ta}$, $\mathrm{Sb}$ [35]; Figure 1B) is hosted by the Sioule nappe, metamorphosed to $600{ }^{\circ} \mathrm{C}, 7-8 \mathrm{kbar}$ [36] at 360-350 Ma (U-Th-Pb on monazite [23]). This nappe is composed of three metasedimentary units, forming antiforms that were cored by several intrusions. The base of the nappe consists of two-mica schist, with a localized occurrence of cordierite. This unit is intruded by two granitic complexes, the Pouzol-Servant laccolith in the south, and the more evolved plutons of Colettes and Beauvoir in the north. The Pouzol-Servant laccolith intruded during the Visean peak of peraluminous magmatic activity (330 $\pm 9 \mathrm{Ma} \mathrm{Rb}-\mathrm{Sr}$ wholerock [37]), also recorded by the resetting of the ${ }^{40} \mathrm{Ar} /{ }^{39} \mathrm{Ar}$ record in metamorphic micas ( 335 Ma [38]). The Beauvoir/Colettes granitic complex was emplaced at 310 Ma [39-41] in this series during the collapse of the Variscan belt. The Echassières district is located only a few kilometers to the east of the crustal-scale strike-slip Sillon Houiller fault, which was active during the Visean and Stephanian (and possibly Westphalian) and inactive during the Namurian [42], remarkably close to the timing of both Pouzol-Servant and Beauvoir/Colettes intrusions. 


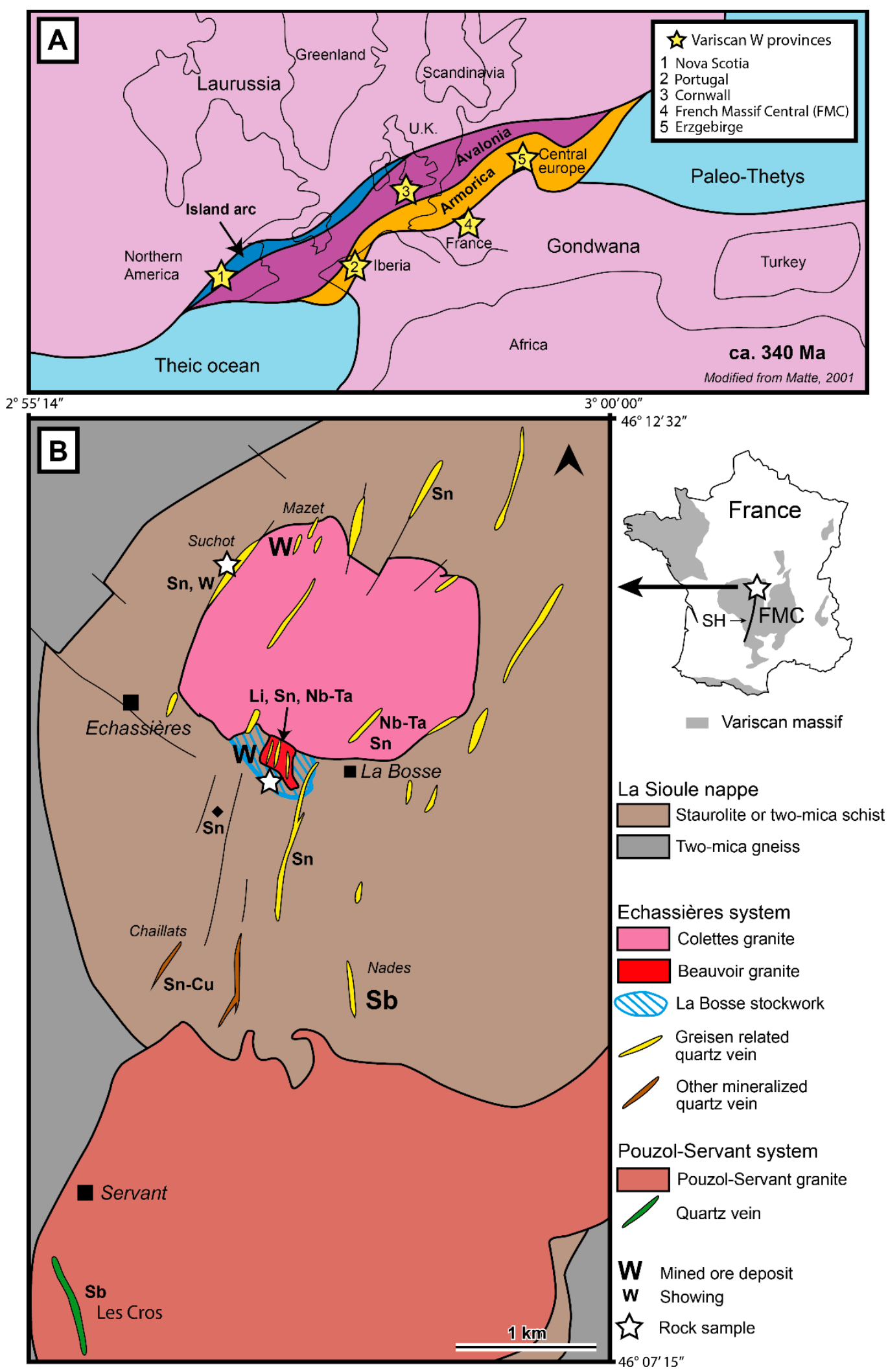

Figure 1. (A): Globe-scale location of the Variscan belt during collision at $340 \mathrm{Ma}$ and localization of present-day main $\mathrm{W}$ provinces, modified after [12]. (B): Geological sketch-map and location of the Echassières district (4 in Figure 1A), modified after [35]. FMC: French Massif Central, SH: Sillon Houiller Fault. 


\section{Tungsten Mineralization}

It has long been recognized that at least two different types of wolframite crystallized in the Echassières district, hübnerite (Mn pole) to the north of the Colettes/Beauvoir massif (Mazet area) and ferberite (Fe pole) to the south, in the La Bosse stockwork [43]. Based on field observations, textural evidence, fluid and mineral chemistry, Monnier et al. [35,44] confirmed previous findings and identified a total of three wolframite generations in the district (Table 1), all present, to various extents, in the La Bosse stockwork:

(1) Wolframite $a$, found exclusively in the La Bosse stockwork, corresponds to the earliest $\mathrm{W}$ mineralization (ferberite pole at $\sim 90 \%$ ) and is hosted by horizontal quartz veins emplaced contemporaneously to multiple aplitic dykes [43].

(2) Wolframite $b$ (Nb-rich ferberite pole at $70 \%$ ) occurs in the stockwork as well as in the surrounding schist, and is associated with cassiterite and pervasive F-rich alteration accompanying emplacement of topaz veins (topaz \pm F-Li rich micas).

(3) Wolframite $c$ (hübnerite pole at $\sim 70 \%$ ) is the last generation recognized in the La Bosse stockwork, where it is associated with the greisen alteration affecting the Beauvoir granite [35,45]. Here it only forms a scant occurrence, while it is much more abundant in a group of sub-vertical $\mathrm{N} 020^{\circ}$-trending proximal quartz veins in the Mazet area $[44,46]$.

The wolframite $b$ generation represents roughly $80 \%$ of the total wolframite tonnage in the Echassières district, while wolframite $a$ and $c$ consist each of about $10 \%$ [44]. Estimated reserves for the La Bosse stockwork and the Mazet veins represent $\sim 5 \times 10^{3}$ and $10^{2}$ metric tons of $\mathrm{WO}_{3}$, respectively $[43,47]$.

Table 1. Main features of the principal wolframite generations from the Echassières district; see $[35,44,45]$ for more details.

\begin{tabular}{|c|c|c|c|c|c|}
\hline $\begin{array}{l}\text { Wolframite } \\
\text { Generation }\end{array}$ & Composition & Paragenesis & Texture & Gangue Minerals & Locality \\
\hline$a$ & Ferberite pole & $\begin{array}{c}\text { Cassiterite, russelite, } \\
\text { Bi metal, rutile, } \\
\text { quartz, biotite }\end{array}$ & $\begin{array}{l}\text { Anhedral mm-sized } \\
\text { crystals, rich mineral } \\
\text { inclusion rich, } \\
\text { corroded face. }\end{array}$ & Quartz veins & $\begin{array}{c}\text { La Bosse } \\
\text { stockwork, } \\
\text { Chaillats veins * }\end{array}$ \\
\hline$b$ & $\begin{array}{l}\text { Ferberite pole, } \\
\mathrm{Nb} \text {-rich } \\
\text { growth zones }\end{array}$ & $\begin{array}{c}\text { Topaz, Nb-rich rutile, } \\
\text { cassiterite, } \\
\text { zinnwaldite }\end{array}$ & $\begin{array}{l}\text { Subhedral to euhedral, } \\
\text { mm to cm-sized crystal, } \\
\text { coeval to topaz }\end{array}$ & $\begin{array}{l}\text { Topaz veins, } \\
\text { altered quartz } \\
\text { veins, altered } \\
\text { schist host }\end{array}$ & $\begin{array}{l}\text { La Bosse } \\
\text { stockwork }\end{array}$ \\
\hline$c$ & Hübnerite pole & $\begin{array}{c}\text { Apatite, muscovite, } \\
\text { quartz }\end{array}$ & $\begin{array}{l}\text { Euhedral crystal, } \mu \mathrm{m} \text { to } \\
\text { cm sized. coeval to } \\
\text { micro-crystalline quartz }\end{array}$ & $\begin{array}{c}\text { Greisen related } \\
\text { quartz veins, } \\
\text { greisen assemblage }\end{array}$ & $\begin{array}{c}\text { Mazet veins, } \\
\text { Beauvoir, La } \\
\text { Bosse stockwork }\end{array}$ \\
\hline
\end{tabular}

${ }^{*}$ Wolframite from Chaillats veins is interpreted as genetically linked to hydrothermal fluids at the origin of wolframite $a[43,45]$ even if the associated paragenesis is clearly different in this locality. This affirmation needs to be confirmed by further studies.

Further south in the district, distal veins (Chaillats and Nades; Figure 1B) enriched in base metal sulfides are also genetically related to the $\mathrm{W}$ mineralization events $[45,48]$.

\section{Materials and Method}

\subsection{Sampling Strategy}

Poor or inexistent outcrop conditions for the granites that potentially sourced the early wolframite generations, plus the absence of commonly dateable minerals (e.g., zircon, monazite) in the different W-bearing veins, prompted us to focus on the associated mineral alteration halos. Samples containing wolframite $a$ and $b$ were collected from quartz and topaz veins from the La Bosse stockwork. Unfortunately, the mine site of Mazet (wolframite $c$ ) has since been remediated and does not outcrop any longer. Therefore, we monitored the alteration halo of the Suchot vein, a nearby proximal vein, equivalent to the Mazet vein (Figure 1B). Previous petrographic (same quartz texture and alteration assemblages [43]) and fluid-inclusion (similar fluid chemistry and P-T path [35]) studies provide clear evidence that Suchot and Mazet veins crystallized from the same fluid. In 
addition, the quartz trace-element signatures of these veins were shown to be statistically indistinguishable [45], providing evident constraints on their genetic relationship. Their crystallization temperatures are also similar, estimated by microthermometric analyses at $\sim 230^{\circ} \mathrm{C}$ and $260^{\circ} \mathrm{C}$ for Suchot and Mazet, respectively [35]. Details on mineral parageneses from the above sites can be found in [44].

\subsection{Analytical Procedures}

Uranium and lead isotopes were measured by LA-ICP-MS on monazite from haloes around topaz veins that crosscut rocks hosting the La Bosse stockwork above the Beauvoir granite apex, as well as from selvages of the Suchot vein. Rutile from the latter vein was also analyzed. Minerals to be dated were first petrographically investigated (Figure 2), notably scanning electron microscopy (SEM), at the Raymond Castaing microcaracterization center (Toulouse University, Toulouse, France) using a Cameca SX5 Electron probe micro analyzer (EPMA). Oxyde composition of rutile and monazite was monitored by EPMA (Supplementary Material Table S1). All analyses (EPMA and LA-ICP-MS) were monitored in situ in thick sections $(200 \mu \mathrm{m})$. Ages are reported below in the form of U-Pb Terra-Wasserburg plots (Figure 3) and the reader is invited to refer to Supplementary Material Table S2 for detailed data. Individual analyses are quoted in the text and Table S2 at 95\% confidence level $(2 \sigma)$, and in Figure 3 with a $1 \sigma$ uncertainty for better clarity. Some pictures of analyzed crystals, ante or post ablation, are available in Supplementary Material Figure S1.

\subsection{Rutile U-Pb Dating}

Rutile analyses were performed at the Géosciences laboratory in Montpellier, using the facilities of the AETE-ISO analytical platform of the OSU OREME (France). A total of 16 crystals were identified from the Suchot vein footwall. Fifty-two analyses were done in situ, using a Thermofinnigan Element 2 XR mass spectrometer coupled to a laser ablation device Lambda Physik Compex 102. U-Pb analyses were performed using a spot size of $51 \mu \mathrm{m}$, within a pre-ablation circle of $75 \mu \mathrm{m}$. Laser frequency was $6 \mathrm{~Hz}$ and energy density $12 \mathrm{~J} / \mathrm{cm}^{2}$. Ablation experiments were conducted under ultra-pure Helium, which enhances sensitivity and reduces $\mathrm{Pb}-\mathrm{U}$ fractionation (e.g., [49]). The He gas stream and the particles from the samples were subsequently mixed with Ar shortly before entering the plasma. Each analysis consisted of $15 \mathrm{~s}$ of gas blank followed by $45 \mathrm{~s}$ of signal acquisition. The reference standard used was R10 rutile (1090 Ma [50]), which was analyzed twice every five unknowns. Uranium content in rutile from Echassières commonly ranges from 5 to 10 ppm.

\subsection{Monazite U-Pb Dating}

Monazite analyses were monitored at the French Geological Survey (BRGM) facilities in Orléans (France). This laboratory is equipped with an ICP-MS X series II spectrometer set up in Xs lens, coupled with a Cetac Excite $193 \mathrm{~nm}$ laser system with short pulse duration. The sample was located in a two-volume cell flushed with helium. The ablation diameter was $12 \mu \mathrm{m}$, using a laser frequency of $2 \mathrm{~Hz}$ and energy density of $3.5 \mathrm{~J} / \mathrm{cm}^{2}$. Reference standard was Madmon monazite (dated at $515 \mathrm{Ma}$ [51]). Quality control was performed with Trebilcock (272 Ma [52]) and Namaqualand (1033 Ma [53]) standards.

Twelve monazite crystals from the metasomatic halo of a polyphase topaz vein were analyzed in situ for a total of 27 analyses. Five monazite crystals from the footwall of the Suchot vein were selected for 16 in-situ analyses in total. Monazite data were reduced using the version 3.0 Glitter ${ }^{\circledR}$ software [54]. Concordia plots and ages calculations were completed using the Isoplot software, version 1.0 [55]. 

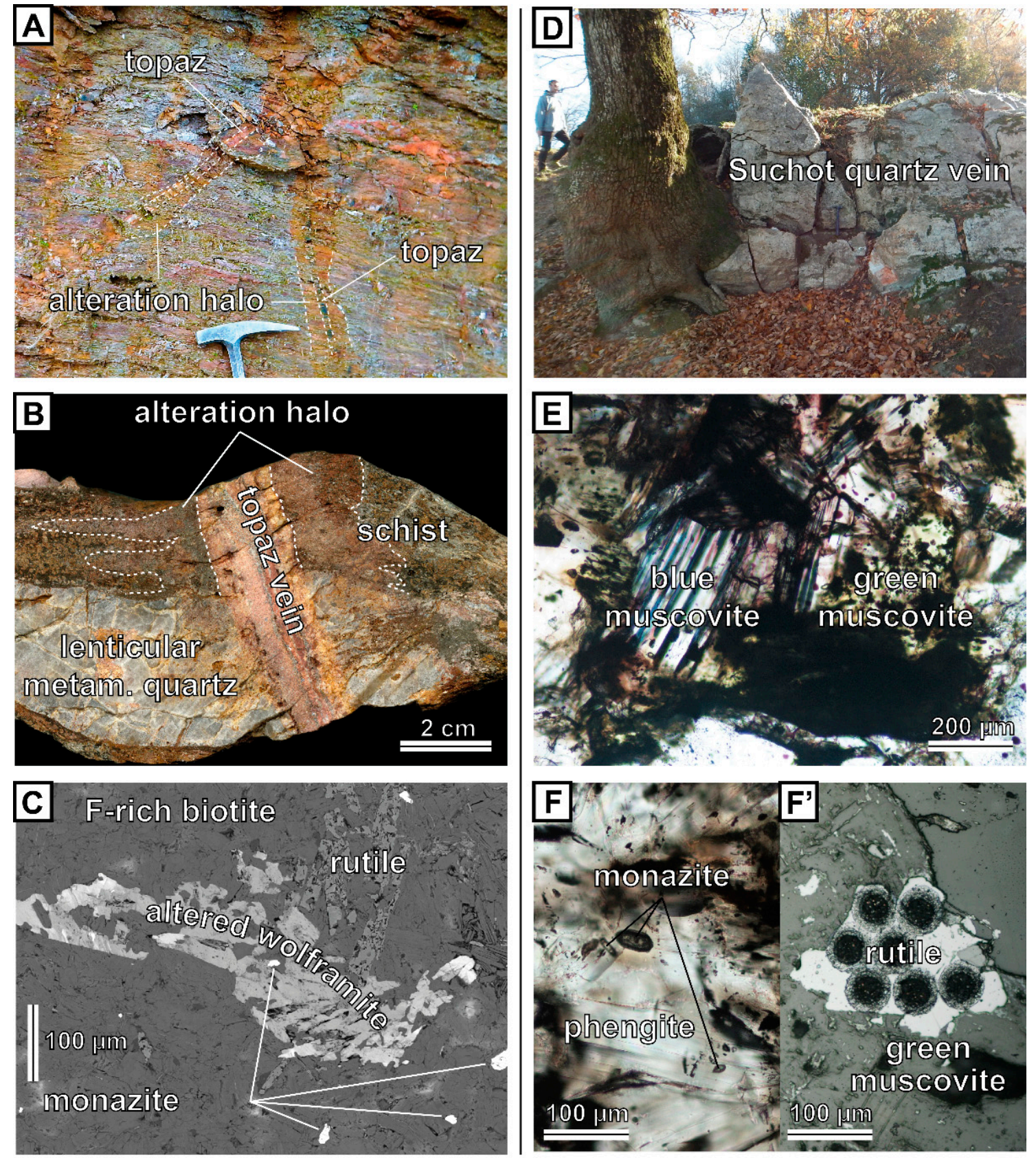

Figure 2. Alteration haloes and mineral textures from the topaz (A-C) and Suchot (D-F) veins. (A): Outcrop image of topaz veins and their alteration halos. Colors are saturated for better clarity. (B): Photograph of topaz vein sample crosscutting the metamorphic foliation. Alteration halo is well marked in the schist. (C): Backscattered electron image of altered wolframite $b$ and associated monazite in the alteration halo of the topaz veins. Matrix of the alteration is mostly composed of F-rich brown micas (D): Outcrop photograph depicting the metric-sized Suchot vein. (E): In the selvage of the Suchot vein, metamorphic minerals are entirely replaced by hydrothermal quartz and two generations of micas: green and pale-blue colored muscovite crystals. Photomicrograph is in Plane-Polarized Light (PPL). (F): Blue muscovite crystals display numerous inclusions of monazite while rutile inclusions are lacking (PPL). $\left(\mathbf{F}^{\prime}\right)$ : Reflected light image of rutile crystal included in green muscovite. Conversely to blue muscovite, monazite inclusion is scarce in this type of micas. 

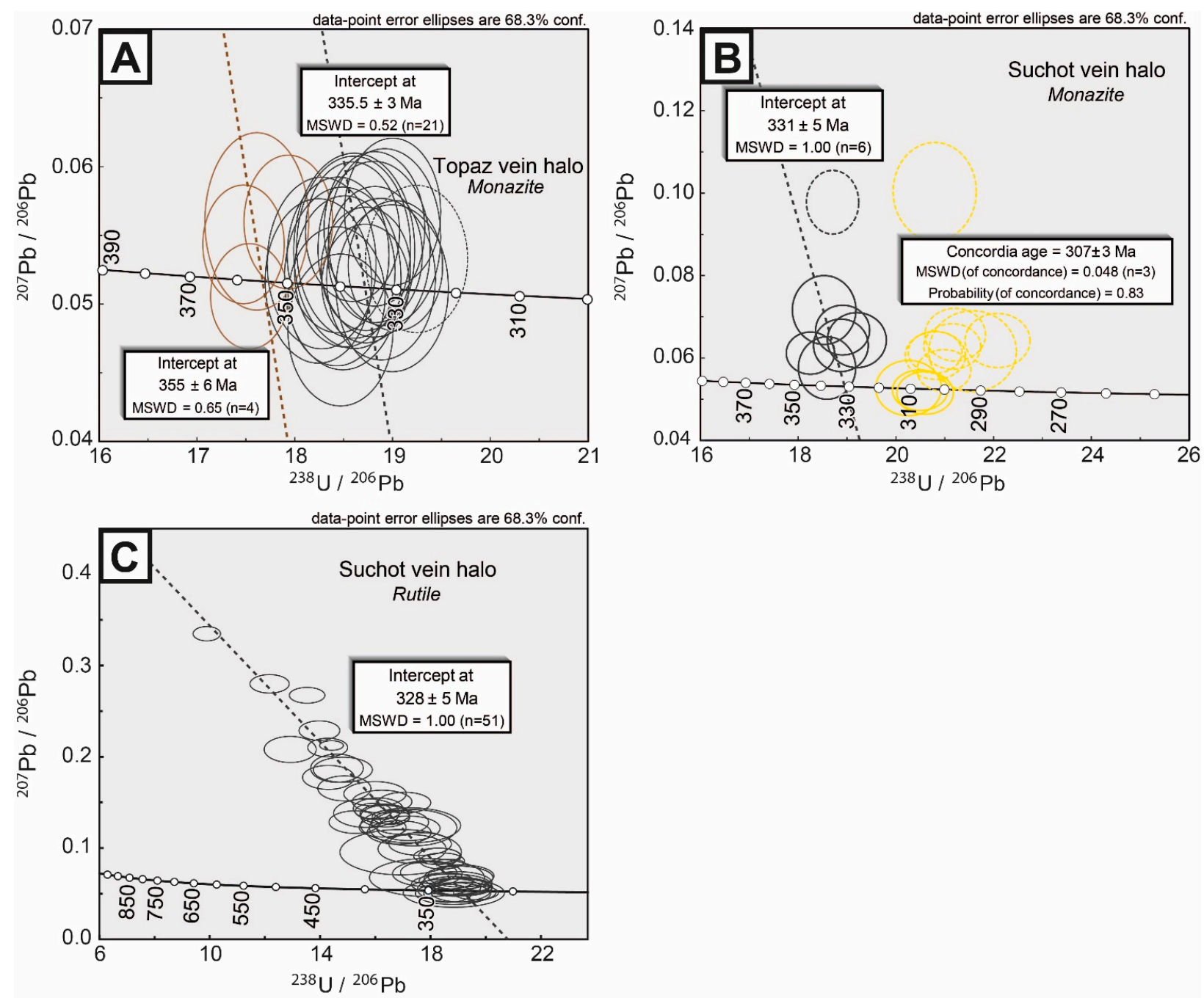

Figure 3. Terra Wasserburg diagram for monazite from topaz veins halos, and monazite and rutile from Suchot vein halo. MSWD: Mean Standard Weighed Deviation. (A) Monazite crystals from topaz vein halo. (B) Monazite crystals from Suchot vein halo. (C) Rutile crystals from Suchot vein halo.

\section{Results}

\subsection{Topaz Veins}

Topaz veins consist of cm-large subvertical veins that crosscut the dm-thick subhorizontal quartz veins of the La Bosse stockwork, as well as the host-rock schistosity (Figure 2A). Topaz veins bear wolframite $b$ and minor F-rich mica. An alteration halo developed in the host schist (Figure 2A,B), marked by similar F-rich hydrothermal micas and accompanied by small amounts of wolframite, topaz and accessory monazite (Figure 2C). Monazite crystals are clearly more concentrated in the halo of topaz veins compared to the fresh schist. Rare core/rim texture was imaged by back scattered electron mapping (see Supplementary Material Figure S1I), while the EPMA analyses were too homogeneous to permit differentiating the two zones by hypothetical major elements variation. Most monazite crystals display homogeneous textures and give an intercept age of $335.5 \pm 3 \mathrm{Ma}$ (Figure 3). In addition, five crystals cores give an older age of $355 \pm 6 \mathrm{Ma}$, interpreted as inheritance of a previous generation.

\subsection{The Suchot Vein}

The meter-sized Suchot vein was emplaced between the western contact of the Colettes granite and the surrounding schist (Figure 2D). Accompanying alteration in the host 
rocks consists of a muscovite-quartz greisen in the granite, while two distinct alteration patterns affect the schist, whereby early green muscovite and $\mathrm{W}$-rich sector-zoned rutile are overprinted by a later quartz and pale-blue muscovite paragenesis (Figure 2E). Abundant monazite and xenotime crystallized contemporaneously, with both the green and blue muscovite varieties (Figure 2F). Monazite grains from both alteration assemblages are commonly euhedral, texturally and chemically homogeneous (Supplementary Material Table S1 and Figure S1). Chemical variations in rutile consist mainly of substitution of $\mathrm{Ti}^{4+}$ by $0.5\left(\mathrm{~W}^{6+}+\mathrm{Fe}^{2+}\right)$ which results in important sector zonings where $\mathrm{WO}_{3}$ contents can reach $6 \mathrm{wt} \%$. Sector zoning is characterized by the propagation of crystal defects at different locations of the crystals during a same growth phase. In zones where $\mathrm{W}$ is more concentrated, the common $\mathrm{Pb}$ is high, probably due to the facilitated incorporation in crystals with important defects and substitutions, and the corresponding analysis plot on a discordia line. This discordia crosscuts a large number of concordant analyses from the $\mathrm{W}$-poor rutile, confirming that the $\mathrm{W}$-poor and $\mathrm{W}$-rich rutile zones are contemporaneous. In situ dating of the W-rich rutile (Figure $2 \mathrm{~F}^{\prime}$ ) yields an age of $328 \pm 5 \mathrm{Ma}$. The two monazite populations display distinct ages of $331 \pm 5 \mathrm{Ma}$ and $307 \pm 3 \mathrm{Ma}$ (Figure 3).

The main textural relationships and absolute ages for both La Bosse stockwork and Suchot areas are summarized in Figure 4.
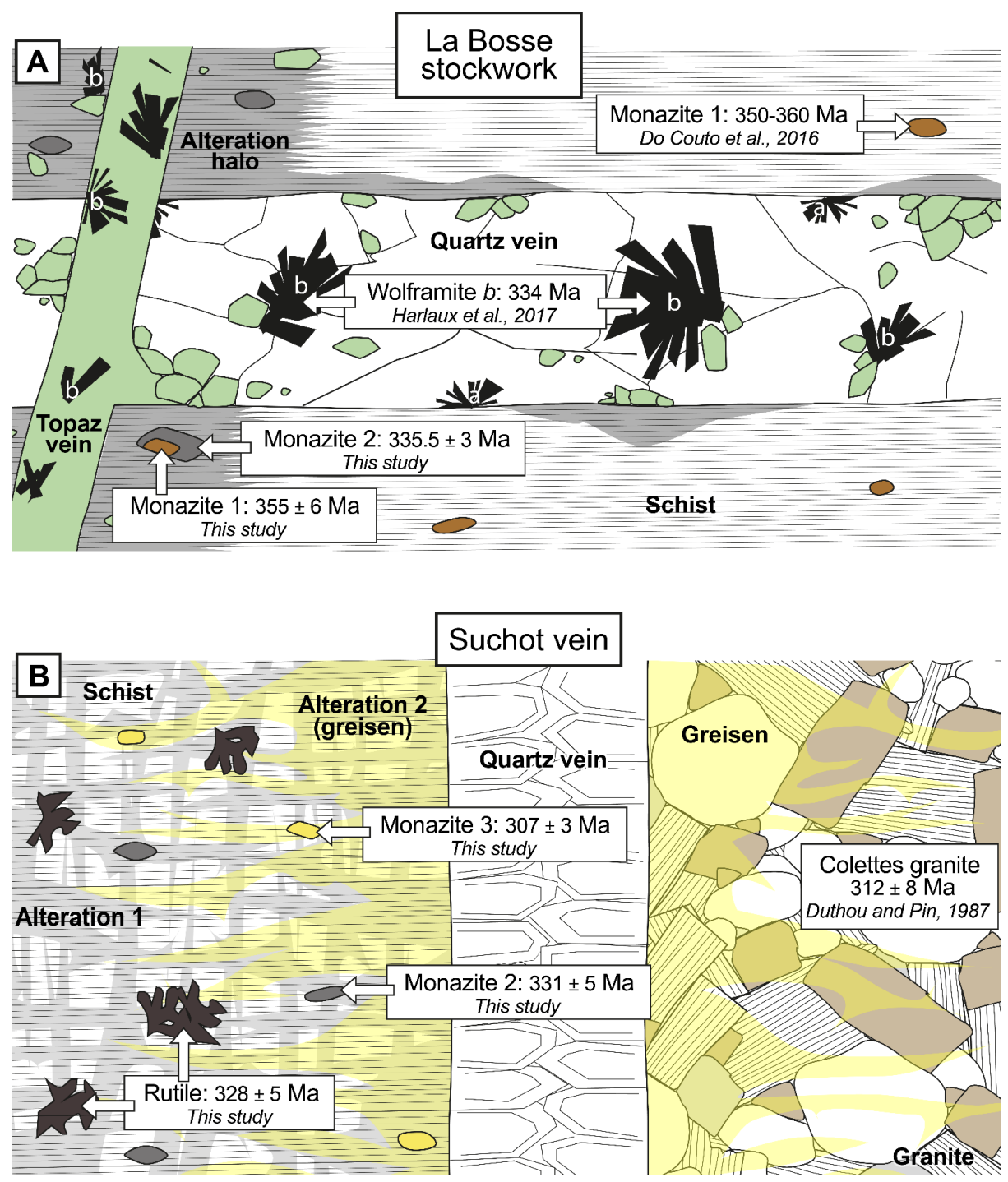

Figure 4. Graphical synthesis of alteration relationships and available ages of the studied rocks. (A) La Bosse stockwork: a-wolframite $a, \mathrm{~b}$-wolframite $b$. (B) Suchot vein. 


\section{Discussion}

\subsection{Deposit Scale Analysis of Tungsten Mineralization}

6.1.1. La Bosse Stockwork (Wolframite $a ;>360 \mathrm{Ma}$ )

The La Bosse stockwork is characterized by quartz veins that are spatially associated with dykes of lamprophyre, microgranite, and K-feldspar rich aplite [43]. Some microgranite and aplitic dikes crosscut the quartz veins and a reciprocal relationship is also observed [43]. Based on these textural observations, the La Bosse stockwork is alleged to have formed from the cooling of succeeding batches of magma and pulses of orthomagmatic fluids, similarly to porphyry systems. Transposition of the La Bosse stockwork into the sub-horizontal schistosity of the Sioule nappe is marked by the deformation of quartz veins (evidences depicted in [43]) and recrystallization of quartz grains by grain boundary migration [44]. The latter texture indicates high temperature deformation and suggests that vein formation occurred before nappe stacking. Quartz recrystallization smoothed the vein/schist boundaries, allowing for the formation of an intermediate zone consisting of a mixture of ancient hydrothermal quartz and metamorphic micas. This contrasts with the sharp contacts commonly observed in veins that were not affected by metamorphism. Garnet and staurolite porphyroblasts, developed in the alteration haloes of quartz veins, contain abundant inclusions of tourmaline and ilmenite. Such modal composition, in some cases up to $10 \%$ for each mineral, likely resulted from precipitation from an orthomagmatic fluid. Metamorphic tourmaline, described in other metamorphic series of the FMC, differs clearly in terms of associated mineral assemblages, their marked growth-zoning and their commonly larger size [56], confirming that the fine-sized and chemically homogeneous tourmaline from La Bosse is of hydrothermal origin, preceding the metamorphic growth of porphyroblasts. All of these observations argue for the crystallization of quartz veins before Barrovian metamorphism in the area. Nevertheless, an absolute age could not be obtained for the wolframite $a$ mineralizing event. It is thus critical to conduct further investigations to constrain the absolute age of the La Bosse dyke and quartz vein formation, given that this porphyry-like mineralization and their relative timing, is an unprecedented event in the FMC. At this time, the older wolframite dated from MCF was wolframite $b$ from Echassières at $\sim 333 \mathrm{Ma}[57]$.

\subsubsection{Barrovian Metamorphism (350-360 Ma)}

In the study area, the units hosting the main mineralization were affected by a regional metamorphic episode that peaked at $\sim 600{ }^{\circ} \mathrm{C}$ and $7 \mathrm{kbar}$ [36], at 350-360 Ma [23]. Metamorphic wolframite was not observed. We interpret the $355 \pm 6 \mathrm{Ma}$ age, obtained from the core of five monazite grains, depicting in Supplementary Material Figure S1, and located in the halo of the topaz vein (Figures 3 and 4), which represents older crystals that had grown during this metamorphic event (Figure 5), confirming the MP/MT metamorphic age of Do Couto et al. [23].

\subsubsection{Topazification Event (Wolframite $b ; \sim 333 \mathrm{Ma}$ )}

Topazification is interpreted to have resulted from the action of a greisen fluid strongly enriched in $\mathrm{F}$ and $\mathrm{Li}$ [35]. This alteration is focused in the La Bosse stockwork area where wolframite $b$ occurs. It consists of $\mathrm{cm}$-thick topaz veins with zinnwaldite haloes and the replacement of quartz by topaz. Wolframite $b$ was dated at $\sim 333 \mathrm{Ma}$ [57], i.e., contemporaneous to the topaz veins (hydrothermal monazite dated at $335.5 \pm 3 \mathrm{Ma}$ in this study; Figure 4A). Similar Visean ages were also obtained from W-rich hydrothermal rutile and monazite ( $328 \pm 5 \mathrm{Ma}$ and $331 \pm 5 \mathrm{Ma}$, respectively) in the altered schist at the contact of the Suchot vein (Figure 3). However, the Suchot vein affected the Colettes granites $(\sim 310 \mathrm{Ma})$ and is related to greisen alteration in the Beauvoir granite (evidenced by quartz trace-element signatures [45]). Consequently, it appears that the Suchot quartz vein postdates a previous alteration that affected the schist (Figure 4B). The strong $W$ enrichment of rutile (up to several $\mathrm{wt} \%$ of $\mathrm{WO}_{3}$, Supplementary Material Table S1) indicates that the fluid that percolated the schist in the Suchot area at $~ 330$ Ma had strong potential for $W$ 
ore deposition [58]. Both the similar Visean age and the W-rich nature of the fluid argue that it is same fluid flowing in the two localities of La Bosse and Suchot. Although greisen fluids are typically correlated to the crystallization of peraluminous granite, there is no direct field evidence for the presence of granitic rocks related to the topazification episode at Echassières. Nevertheless, the age constraint on the topazification event $(\sim 333 \mathrm{Ma}$; Figure 5) corresponds to the peak of Visean peraluminous magmatism in the FMC [59]. The most proximal Visean granite in the Echassières district, the 330 Ma-old Pouzol-Servant granite [37], outcrops 2.5 kilometers south of the La Bosse stockwork and is a conceivable candidate for sourcing the F-rich greisen fluid. It is also possible that another granite, or an off-shoot of the Pouzol-Servant granite, was emplaced in the northern antiform of the Sioule nappe, a few kilometers deeper than the actual level of erosion in the Echassières district.

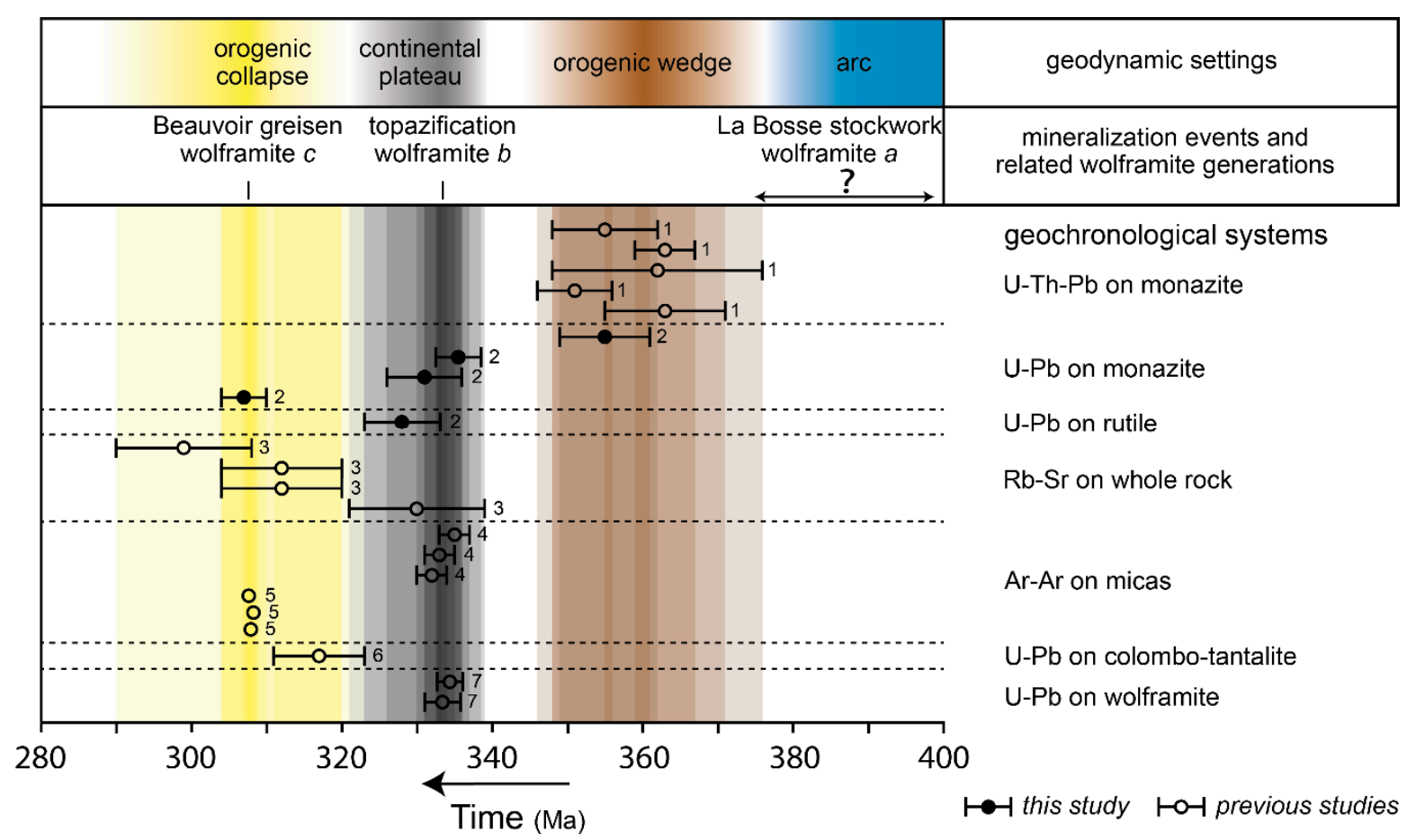

Figure 5. Compiled ages of various formations from the Sioule nappe. 1: monazite from main metamorphic facies [23]. 2: result from this study. 3: whole rock ages (from oldest to youngest) of the Pouzol-Servant, Colettes, and Beauvoir (unit 1 and 2) granites [37,39]. 4: micas from main metamorphic facies [38]. 5: igneous lepidolite of the three main units of the Beauvoir granite [40]. Symbols are larger than error bars. 6: Colombo-tantalite in the Beauvoir granite greisen [41]. 7: Wolframite $b$ ([57]; identification by [44]). The question mark for the wolframite- $a$ age indicates that this generation was only constrained in relative terms, as no absolute age is available for this event in the district, to date.

\subsubsection{Beauvoir Greisen (Wolframite $c$; 310 Ma)}

The emplacement of the Beauvoir RMG was dated at 310 Ma [39-41]. The granite body, as the contemporaneous dykes of the same facies, crosscut the La Bosse quartz vein stockwork and the later topaz veins located in the same place. The Beauvoir granite is not affected by metamorphism, nor alteration of the topazification episode. Greisen affected the apex of the granite body and the surrounding host rock, mainly by pervasive and veins-related alteration, respectively. In contrast to the greisen episode which was responsible for the topazification described above, the greisen in the Beauvoir granite is characterized by F-poor muscovitization [44]. The proximal veins are mineralized in $\mathrm{W}$ to a varied extent, i.e., wolframite is absent in the Suchot vein, while the Mazet veins contain high-grade mineralization. The age of $307 \pm 3 \mathrm{Ma}$, obtained herein for the second monazite generation in the Suchot vein halo, confirms that the Suchot vein and other proximal veins formed from greisen fluids originating from the Beauvoir granite, as already established 
based on quartz trace-element chemistry [45] and fluid inclusion data [35]. This event is the last W mineralization related to magmatism in the Sioule nappe (Figure 5).

\subsection{Geodynamic-Tectonic Context of Tungsten Mineralization}

In this section, we compare the geological record of the Echassières district with paradigms from well-known $\mathrm{W}$ provinces worldwide in order to understand the circumstances favoring an emplacement of $\mathrm{W}$ fertile igneous bodies, at the orogenic scale. Below, different parageneses are compared. However, skarn-type deposits are not dealt with because they are intrinsically related to carbonate host rocks, which are absent in our system.

\subsubsection{Wolframite $a$-(Devonian Arc Magmatism)}

Emplacement of the La Bosse stockwork episode is only poorly constrained, and so is the pre-collision settings that globally prevailed in the FMC during the Devonian (see discussion in [34]). Stockwork formation at La Bosse could not have taken place at depths greater than $\sim 5 \mathrm{~km}$, due to the inhibition of host-rock fracturing by increasing lithostatic pressure [59,60], consistent with the general occurrence of stockwork in near-surface porphyry-related settings. The dykes of La Bosse stockwork are of alkaline affinity and may be linked to the calk-alkaline to alkaline series described elsewhere in northern Massif Central and known as the "Limousin tonalite belt" [61,62]. This magmatism was dated at 360-380 Ma [30], which is syn HP metamorphism recorded by the nappe package in the western FMC $[18,20,21]$. It is considered to represent the melting of a dual source, consisting of a subduction-modified mantle and the underplated crust, during the northward subduction of the Rheic ocean [63]. A similar interpretation was proposed for the tonalite series magmatism of central Europe, dated from 370 to 340 Ma [64].

It is well known that oceanic closure favors the formation of fertile $\mathrm{W}$ granites, which is amply illustrated by occurrences in the Sn-W belts of the Andes and the Nanling Range (China), two of the largest $\mathrm{W}$ provinces in the world. Polymetallic (including $\mathrm{W}$ ) porphyry deposits are common in both belts $([65,66]$ for the Andean belt and $[9,11]$ for the Nanling range). The Acadian Province in New Brunswick, an early part of the Variscan belt in North America [12], hosts a vast $\mathrm{W}$ province. Here, "porphyry like" dyke series are interpreted to have led to the formation of $\mathrm{W}(\mathrm{Mo}, \mathrm{Bi})$ stockwork and isolated regional veins [67-69]. As is the case for wolframite $a$ at Echassières [44], Bi is closely associated with wolframite mineralization (ferberite pole) in several deposits in New Brunswick [67,70-72]. Moreover, mineralization ages $(\sim 370 \mathrm{Ma},[71,73,74])$ are compatible with the inferred timing of wolframite $a$. Nevertheless, tectonic accretion of the Avalonia micro-continent predates the magmatism responsible for Acadian W and Sn deposits [72], which is inconsistent with the pre-metamorphic context of wolframite $a$ deposition at Echassières. Regardless, metal enrichment described in all of the above-mentioned porphyry systems $(\mathrm{W}, \mathrm{Bi}, \mathrm{Cu}$, $\mathrm{Zn}$ ) is similar to that observed in the La Bosse stockwork and sulphide-rich (e.g., sphalerite, stannite, arsenopyrite, chalcopyrite) Chaillats veins, which have been tied to the La Bosse episode by the trace-element chemistry of quartz [45]. To our knowledge, all wolframite described in porphyry deposits consist of the ferberite (Fe-rich) pole, as is the case in the La Bosse stockwork.

Consequently, based on a range of indications (similar magma composition, deposit geometry, pre-collisional timing, and hydrothermal paragenesis), we propose that La Bosse stockwork represents a porphyry system associated with arc-related magmatism in the upper plate of a subduction zone. Furthermore, we suggest that the Sioule series was intruded by these magmas during closure of the Medio-European Ocean, represented by the NEF (Nort-sur-Erdre Fault) suture, south of the Armorica continental ribbon (Figure 6A). 

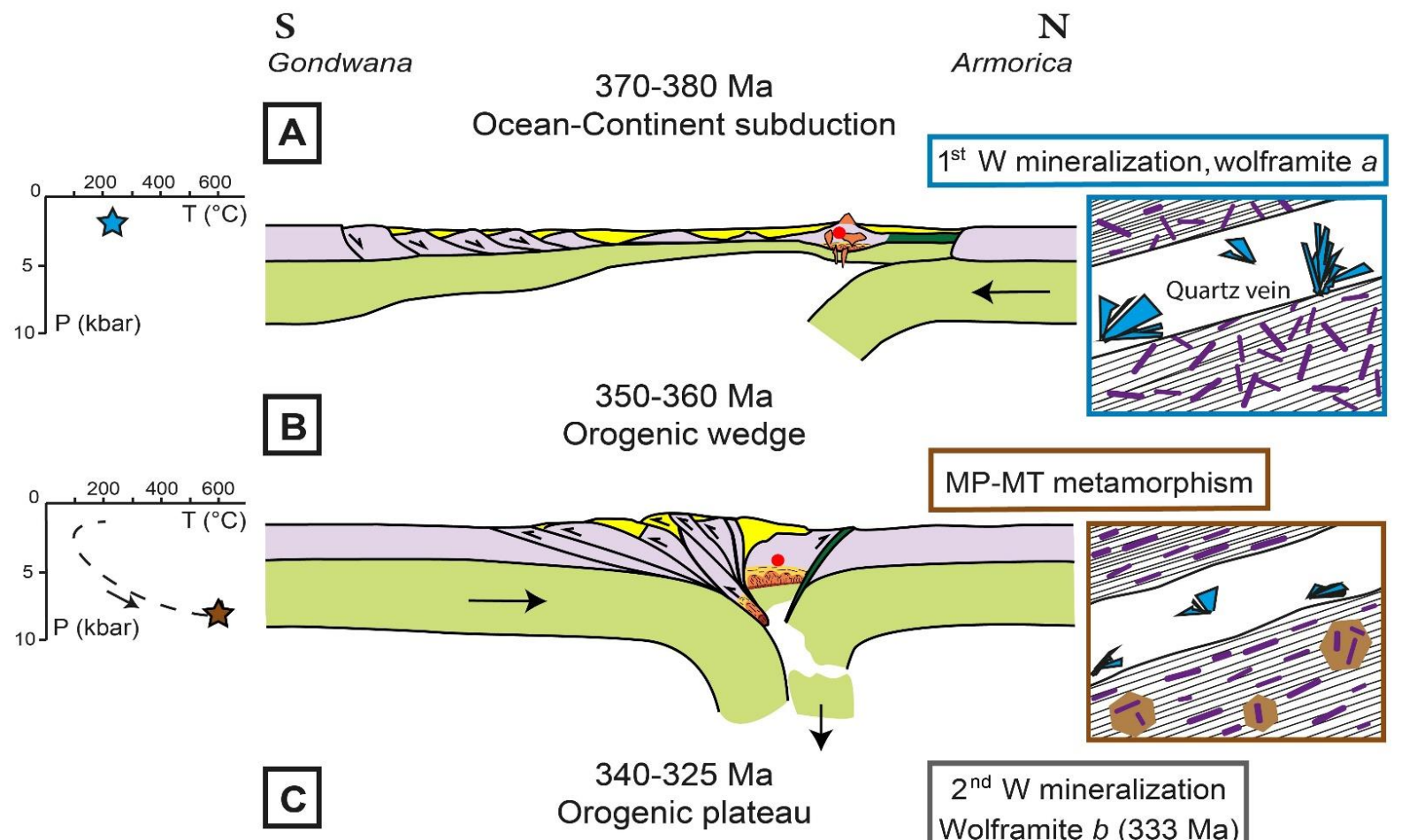

$2^{\text {nd }} \mathrm{W}$ mineralization

Wolframite $b(333 \mathrm{Ma})$
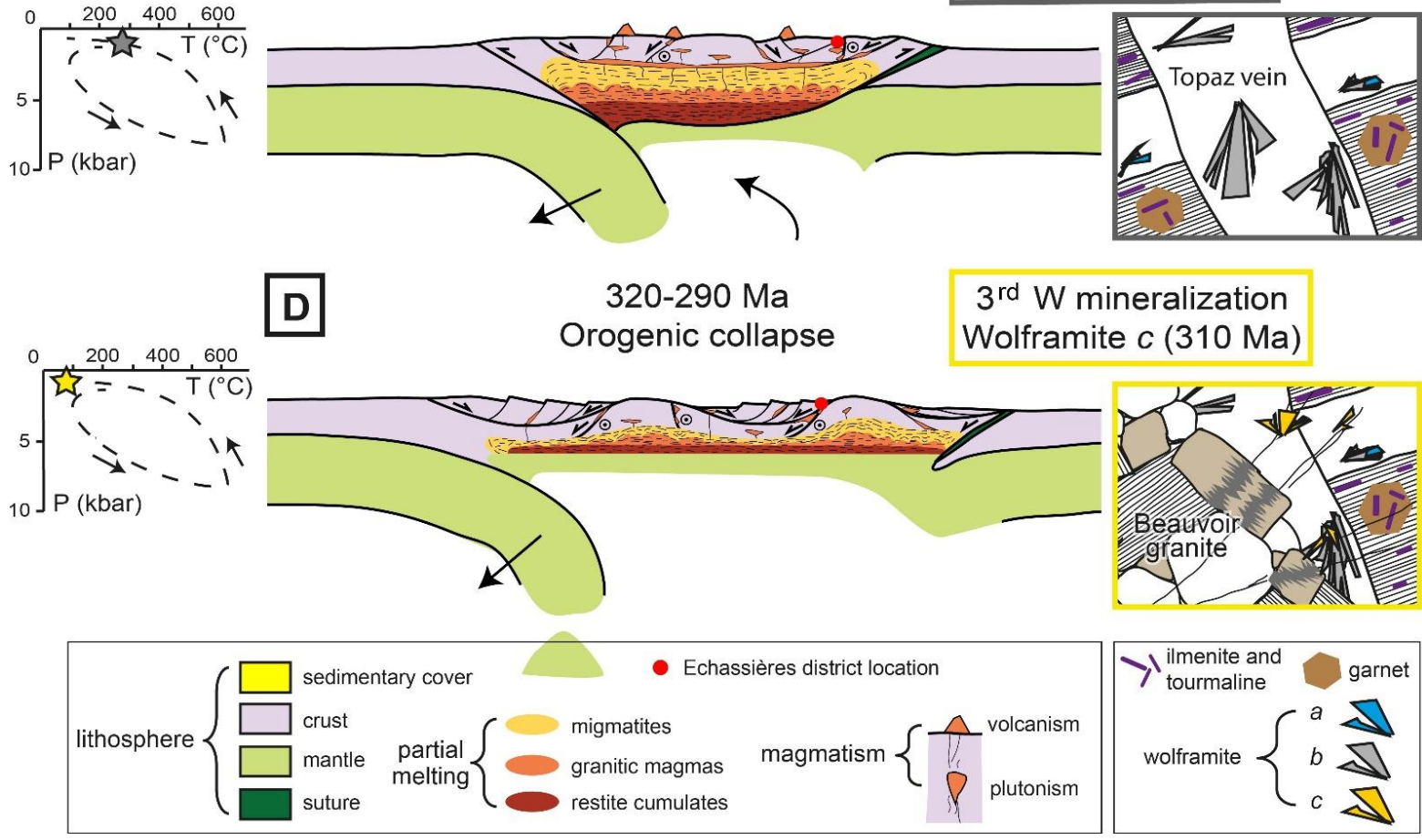

Figure 6. Geodynamic settings and associated petrographic evidences for multiple W mineralizations in the Echassières district. PT-path is constrained by metamorphic assemblages [23,36], fluid inclusion microthermotetric data from [35], and compilation of geochronological data compiled in the Figure 5. (A) Ocean-Continent subduction. (B) Orogenic wedge. (C) Orogenic plateau. (D) Orogenic collapse.

\subsubsection{Wolframite $b$-(Orogenic Plateau)}

During the early Carboniferous, ongoing plate convergence and orogenic evolution (Figure 6B) is marked by the outward propagation of the Variscan front [38], by the activation of orogenic scale transcurrent shear zones [75,76] and detachments [77] as well as by widespread MP/MT Barrovian metamorphism $[21,23,78]$. This period is followed at 
Visean by the emplacement of both crustal-derived and mantle-derived magmas in the form of plutons and volcanic tuffs, preferentially localized along transcurrent shear zones and pull-apart basins $[33,42,79]$. These features are attributed to the development of an orogenic plateau (Figure 6C) caused by the gravity-driven flow of a partially molten orogenic root $[34,80]$. The required increase in temperature might result from the combination of the disintegration of radioactive isotopes concentrated in the continental crust and asthenospheric upwelling induced by slab retreat [33,34]. At $\sim 333 \mathrm{Ma}$, deposition of wolframite $b$ occurs at a shallow depth (maximum of a few kilometers, constrained by fluid inclusions microthermometry [35]), revealing exhumation of about $20 \mathrm{~km}$ since $\sim 355 \mathrm{Ma}$ (metamorphic assemblages recorded at $\sim 7 \mathrm{kbar}[23,36]$ ).

The geological setting for wolframite $b$ mineralization in the Echassières district is comparable to the one inferred for the Erzgebirge province in central Europe, which experienced widespread post-collisional peraluminous magmatism, with only relatively limited contamination by mantle-derived magma [64]. In contrast, an important mantle contribution is evidenced by numerous calc-alkaline plutons in the Ossa-Morena Zone of the Variscan Iberic belt [81]. As for the Echassières district, the main event of W-Sn mineralization in the Erzgebirge (325-315 Ma; refs. [82,83]) postdated the metamorphic peak by $15 \mathrm{Ma}$, which is dated at $\sim 340 \mathrm{Ma}$ in the Saxo-Bohemian zone [64,83,84]. Recently, studies on the rare-metal potential of Himalayan leucogranites [85] provided evidence that these intrusions were followed by $\mathrm{Sn}-\mathrm{W}$ mineralizations [86,87]. We suggest that Visean peraluminous granitic plutons of the FMC, were emplaced in a similar tectonic context marked by growth of an orogenic plateau associated with the lateral expansion of the zone of thickened crust accommodated by strike-slip crustal faults and the horizontal flow of the partially molten ductile crust. Interestingly, post-collisional granites from the Himalaya and the Erzgebirge have some hydrothermal mineral parageneses in common, notably Fe-rich wolframite, $\mathrm{W}$-rich and $\mathrm{Nb} /$ Ta-rich rutile, $\mathrm{F} /$ Li-rich micas, and variable amounts of sulfides.

\subsubsection{Wolframite $c$-(Orogenic Collapse)}

RMG are commonly associated with wolframite mineralizations, although the latter are not economic in most cases, at present. These granites are found in all European Variscan provinces, e.g., Argemela granite in Portugal, Podlesí granite in the Erzgebirge, St. Austell granite in Cornwall (Figure 1A). In some massifs, such as in the FMC and central Europe, a second pulse of peraluminous magma was emplaced 15-20 Ma after the peak of peraluminous post-collisional magmatic activity $[29,64,83,88,89]$. In the FMC, this magmatism is characterized by plutons emplaced at a shallow depth and dykes extremely enriched in rare metals [29], while in central Europe magmatism spans from little to highly evolved compositions, producing an important volcanic episode [90] and related mineralization [83], with minor W mineralization [89]. Despite a paucity of data and disputed ages [41], similar timing to that observed in the FMC ( 310 Ma) was obtained for some W-related evolved granite in the Iberian province [91-94]. In the FMC, orogenic collapse induced the exhumation and rapid crystallization of a partially molten orogenic root as well as the emplacement of the last plutons in detachments and strike-slip shear zones [34]. In the case of the Echassières district, the reactivation of the Sillon Houiller fault was probably responsible for the ascending of the Beauvoir RMG (Figure 6D), after playing a key role in magma transport during the Visean [42]. It is therefore noteworthy that a geodynamic setting marked by orogenic gravitational collapse can promote the emplacement of highly evolved melts, with another example being the RMG in Egypt (e.g., Abu Dabbab [95] and Gabal El-Erediya [96] RMG). Variscan RMG systematically show greisen alteration, and is commonly characterized by Mn-rich wolframite occurrence [97], accompanied by phosphates (e.g., apatite, montebrasite), columbite-group minerals, and scarce sulfides. Contrarily to Visean systems, rutile is absent.

We should point out that other regions of the Variscan belt, such as Cornwall (U.K.) or southern Poland, underwent a last magmatic episode related to $\mathrm{W}$ mineralizations at 
$\sim 290 \mathrm{Ma}$. Nevertheless, the chemical features of the magma and regional tectonic constrains are more typical of within plate and rifting magmatism per se than orogenic collapse [98,99].

\subsection{Tungsten Fertility: Accumulation Rather Than Reworking}

The critical role of the hydrothermal fluid in $\mathrm{W}$ concentrating and deposition is unquestionable and has already been highlighted and discussed in detail in [35]. However, despite the observation that several generations of wolframite are superposed in the Echassières veins, remobilization of previously precipitated $W$ by fluids was probably only a minor process, as evidenced by only scarce partial replacement of wolframite $a$ by $b$ and then wolframite $a$ or $b$ by $c[44,46]$. Below, we will discuss the role of magmatic processes, in particular concerning wolframite $b$ and $c$, for which we have sufficient constraints.

Several parameters that may have favored $\mathrm{W}$ mineralization include (listed as a function as their relative chronology): sedimentary or magmatic pre-enrichment of the source; partitioning during anatectic reactions; low degrees of partial melting; structural control on magma migrations, high degrees of fractionation; magmatic assimilation; and orthomagmatic fluid mobilization, transport and deposition. Some of these parameters may be invoked for several of the wolframite generations at Echassières.

During the Visean (wolframite $b$ ), the formation of an orogenic plateau is accompanied by widespread partial melting of the middle and lower crust. Some metasedimentary units can be relatively enriched in these metals, via primary sedimentation, paleoplacer formation, or previous intrusion of arc related magmatism. Segregation of a melt enriched in an incompatible element, in particular, rare metals, would be favored at the onset of partial melting of the metasedimentary units. Lastly, magma ascension and associated fractional crystallization is strongly dependent on tectonic activity. All of these processes are subordinate to local chemical and physical characteristics, which would explain the contrasting occurrence of $\mathrm{W}$ mineralization only for some of the numerous peraluminous Visean/Namurian granites outcropping in the FMC [57].

Late Carboniferous (wolframite $c$ ) gravitational collapse of the orogenic plateau resulted in exhumation and cooling-crystallization of the partially molten orogenic root. At this stage, most magma crystallized in place, i.e., in actual migmatite leucosomes, resulting in important enrichment in fluxing elements by fractional crystallization in few pockets of residual melt. This highly evolved melt crystallized after only limited migration, as attested by the common occurrence of evolved pegmatites in late-Variscan anatectic domes (e.g., Montagne Noire, Velay). Nevertheless, the migration of magmas out of the partially molten zone was localized along strike-slip shear zones and detachments, and led to the formation of small bodies of extremely evolved melt, RMG, which crystallized at a shallow depth.

It is thus proposed that the occurrence of three generations of wolframite is not a result of local dissolution/precipitation of the $\mathrm{W}$ stock but was produced by the contributions of three juvenile plutons during arc, plateau, and late orogenic magmatism that caused superposition of $\mathrm{W}$ mineralization in the Echassières district.

\section{Conclusions}

Investigation of datable minerals in halos of $\mathrm{W}$ mineralized veins in the Echassières district has provided a chronological record allowing the deciphering of the history of superimposed alterations by different orthomagmatic fluid pulses, during polyphased $\mathrm{W}$ mineralization. A global result of this study is the demonstration that the Sioule Nappe has recorded the different stages of orogenic evolution, including construction of the orogenic wedge, propagation of the orogenic plateau, and orogenic gravitational collapse, all of which favored fertile granite emplacement resulting in the build-up of the outstanding Echassières metallogenic district. A number of specific findings are noted below:

$\mathrm{W}$ deposition was strongly controlled by the orogenic setting, in particular for wolframite $b$ and $c$. These share similar morphologies and parageneses with equivalent deposits in other Variscan massifs of similar relative age with respect to Barrovian metamorphism (i.e., 20 and $40 \mathrm{Ma}$ after peak of metamorphism). 
- The poor state of preservation and the absence of absolute age did not allow us to clearly define the palogeography of wolframite $a$, nor to pinpoint clearly its genetic model, even if it shares several features with porphyry W deposits in New Brunswick, the Andean belt and in the Nanling range.

- The occurrence of a second pulse of peraluminous activity $20 \mathrm{Ma}$ after the peak of peraluminous magmatic activity is a reproducible observation in several Variscan provinces and is potentially extendable to other orogenic belts, with implications for the exploration of magmatic related commodities.

- Crustal fault activity is a preponderant constraint on W-rich magma production and transport during all stages of belt evolution, from the closure of an ocean, crustal thickening, growth of an orogenic plateau, or orogenic gravitational collapse.

- It is worth mentioning that unraveling the paragenesis of $\mathrm{W}$ deposits at a local scale may provide crucial insights into their geodynamic-tectonic setting. Roughly, ferberite accompanied by Mo, Bi and Ti enrichment with sulfide-rich parageneses can be considered typical of porphyry systems; ferberite and $\mathrm{Nb}-\mathrm{Ta}, \mathrm{Ti}, \mathrm{F}, \mathrm{Li}$ enrichment is a possible mark of post-collisional peraluminous magmatism; while hübnerite, low sulfides occurrence and presence of $\mathrm{Nb}-\mathrm{Ta}, \mathrm{Li}, \mathrm{F}$, P characterize RMG, which, in the case of the Variscan belt, emplaced during orogenic collapse and rifting initiation.

Supplementary Materials: The following are available online at https: / www.mdpi.com/article/ 10.3390/min11090923/s1.In Supplementary Materials we have included the following: two tables containing raw microprobe and U-Pb-Th LA-ICP-MS data (Tables S1 and S2), and a figure imaging the analyzed samples (Figure S1). Caption of Figure S1: details of minerals dated (pre or post laser ablation) during this study. All images were taken using backscattered electron, excepted the image (B) in reflected light. (A) and (B): Same rutile crystal before and after laser ablation. (A) and (C): rutile crystals exhibit sector zoning, due to incorporation to up to $5 \mathrm{wt} \%$ of $\mathrm{WO}_{3}$ (see EPMA analyses in Table S1) in the pale grey sectors. (D) to (F): Monazite crystals in alteration halos of topaz veins. $(\mathrm{G})$ and $(\mathrm{H})$ : Homogeneous monazite crystals in alteration halos of Suchot vein. (I): Two monazite crystals displaying a core and overgrowth texture.

Author Contributions: The corresponding author will be the first author. All authors have of course been substantially involved in preparing this work, whether by contributing in the field, lab work, supervision, etc. (cf. detailed contributions listed below). Conceptualization, L.M., O.V. and J.M.; methodology, L.M., P.L. and O.B.; validation, O.V., O.B., J.M., D.B., L.B. and E.G.; formal analysis, P.L. and O.B.; investigation, L.M.; writing—original draft preparation, L.M., S.S., J.M.; writing-review and editing, L.M., J.M., S.S., O.V., O.B., A.B., L.B., D.B., E.G.; visualization, L.M.; supervision, J.M., D.B., L.B. and S.S.; project administration, J.M., D.B., L.B. and S.S.; funding acquisition, J.M. and L.B. All authors have read and agreed to the published version of the manuscript.

Funding: The BRGM (French geologic survey), the university of Toulouse, and the CNRS funded this study.

Data Availability Statement: Data is contained within the article and in Supplementary Materials S1 and S2.

Acknowledgments: We warmly thank the Minerals editorial board and two anonymous reviewers which critically improved the quality of this work.

Conflicts of Interest: The authors declare no conflict of interest.

\section{References}

1. Ballard, J.R.; Palin, J.M.; Williams, I.S.; Campbell, I.H.; Faunes, A. Two ages of porphyry intrusion resolved for the super-giant Chuquicamata copper deposit of northern Chile by ELA-ICP-MS and SHRIMP. Geology 2001, 29, 383-386. [CrossRef]

2. Wang, Z.; Cheng, H.; Zong, K.; Geng, X.; Liu, Y.; Yang, J.; Wang, C.Y. Metasomatized lithospheric mantle for Mesozoic giant gold deposits in the North China craton. Geology 2020, 48, 169-173. [CrossRef]

3. Song, W.; Xu, C.; Smith, M.P.; Chakhmouradian, A.R.; Brenna, M.; Kynický, J.; Tang, H. Genesis of the world's largest rare earth element deposit, Bayan Obo, China: Protracted mineralization evolution over $\sim 1$ b.y. Geology 2018, 46, 323-326. [CrossRef]

4. Lecumberri-Sanchez, P.; Vieira, R.; Heinrich, C.A.; Pinto, F.; Wälle, M. Fluid-rock interaction is decisive for the formation of tungsten deposits. Geology 2017, 45, 579-582. [CrossRef] 
5. Korges, M.; Weis, P.; Lüders, V.; Laurent, O. Depressurization and boiling of a single magmatic fluid as a mechanism for tin-tungsten deposit formation. Geology 2018, 46, 75-78. [CrossRef]

6. Cao, J.; Wu, Q.; Yang, X.; Kong, H.; Li, H.; Xi, X.; Liu, B. Geochronology and genesis of the Xitian W-Sn polymetallic deposit in Eastern Hunan Province, South China: Evidence from zircon $\mathrm{U}-\mathrm{Pb}$ and muscovite Ar-Ar dating, petrochemistry, and wolframite Sr-Nd-Pb isotopes. Minerals 2018, 8, 111. [CrossRef]

7. Li, H.; Cao, J.; Algeo, T.J.; Jiang, W.; Liu, B.; Wu, Q. Zircons reveal multi-stage genesis of the Xiangdong (Dengfuxian) tungsten deposit, South China. Ore Geol. Rev. 2019, 111, 102979. [CrossRef]

8. van Daele, J.; Hulsbosch, N.; Dewaele, S.; Boiron, M.C.; Piessens, K.; Boyce, A.; Muchez, P. Mixing of magmatic-hydrothermal and metamorphic fluids and the origin of peribatholitic Sn vein-type deposits in Rwanda. Ore Geol. Rev. 2018, 101, 481-501. [CrossRef]

9. Zhao, Z.; Fu, T.Y.; Liu, C.; Wang, D.H.; Sheng, J.F.; Li, W.B.; Chen, Y.C. A synthesis of mineralization style and regional distribution and a proposed new metallogenic model of Mesozoic W-dominated polymentallic deposits in South China. Ore Geol. Rev. 2021, 104008. [CrossRef]

10. Groves, D.I.; Bierlein, F.P. Geodynamic settings of mineral deposit systems. J. Geol. Soc. 2007, 164, 19-30. [CrossRef]

11. Zhao, W.W.; Zhou, M.F.; Li, Y.H.M.; Zhao, Z.; Gao, J.F. Genetic types, mineralization styles, and geodynamic settings of Mesozoic tungsten deposits in South China. J. Asian Earth Sci. 2017, 137, 109-140. [CrossRef]

12. Matte, P. The Variscan collage and orogeny (480-290 Ma) and the tectonic definition of the Armorica microplate: A review. Terra Nova 2001, 13, 122-128. [CrossRef]

13. Burg, J.P.; Matte, P. A cross section through the French Massif Central and the scope of its Variscan geodynamic evolution. Z. Dtsch. Geol. Ges. 1978, 1, 429-460. [CrossRef]

14. Burg, J.P.; Matte, P.; Leyreloup, A.; Marchand, J. Inverted metamorphic zonation and large-scale thrusting in the Variscan Belt: An example in the French Massif Central. Geol. Soc. Spec. Publ. 1984, 14, 47-61. [CrossRef]

15. Ledru, P.; Lardeaux, J.M.; Santallier, D.; Autran, A.; Quenardel, J.M.; Floc'h, J.P.; Ploquin, A. Où sont les nappes dans le Massif central français? Bull. Société Géologique Fr. 1989, 1, 605-618. [CrossRef]

16. Matte, P. Tectonics and plate tectonics model for the Variscan belt of Europe. Tectonophysics 1986, 126, 329-374. [CrossRef]

17. Matte, P. Accretionary history and crustal evolution of the Variscan belt in Western Europe. Tectonophysics 1991, 196, 309-337. [CrossRef]

18. Faure, M.; Mezeme, E.B.; Cocherie, A.; Melleton, J.; Rossi, P. The South Millevaches Middle Carboniferous crustal melting and its place in the French Variscan belt. Bull. Société Géologique Fr. 2009, 180, 473-481. [CrossRef]

19. Ballèvre, M.; Catalán, J.R.M.; López-Carmona, A.; Pitra, P.; Abati, J.; Fernández, R.D.; Martínez, S.S. Correlation of the nappe stack in the Ibero-Armorican arc across the Bay of Biscay: A joint French-Spanish project. Geol. Soc. Spec. Publ. 2014, 405, 77-113. [CrossRef]

20. Lotout, C.; Pitra, P.; Poujol, M.; Anczkiewicz, R.; Van Den Driessche, J. Timing and duration of Variscan high-pressure metamorphism in the French Massif Central: A multimethod geochronological study from the Najac Massif. Lithos 2018, 308, 381-394. [CrossRef]

21. Benmammar, A.; Berger, J.; Triantafyllou, A.; Duchene, S.; Bendaoud, A.; Baele, J.M.; Diot, H. Pressure-temperature conditions and significance of Upper Devonian eclogite and amphibolite facies metamorphisms in southern French Massif central. Bull. Société Géologique Fr. 2020, 191, 1-28. [CrossRef]

22. Bellot, J.P.; Roig, J.Y. Episodic exhumation of HP rocks inferred from structural data and PT paths from the southwestern Massif Central (Variscan belt, France). J. Struct. Geol. 2007, 29, 1538-1557. [CrossRef]

23. Do Couto, D.; Faure, M.; Augier, R.; Cocherie, A.; Rossi, P.; Li, X.H.; Lin, W. Monazite U-Th-Pb EPMA and zircon U-Pb SIMS chronological constraints on the tectonic, metamorphic, and thermal events in the inner part of the Variscan orogen, example from the Sioule series, French Massif Central. Int. J. Earth Sci. 2016, 105, 557-579. [CrossRef]

24. Malavieille, J.; Guihot, P.; Costa, S.; Lardeaux, J.M.; Gardien, V. Collapse of the thickened Variscan crust in the French Massif Central: Mont Pilat extensional shear zone and St. Etienne Late Carboniferous basin. Tectonophysics 1990, 177, 139-149. [CrossRef]

25. Burg, J.P.; Vanderhaeghe, O. Structures and way-up criteria in migmatites, with application to the Velay dome (French Massif Central). J. Struct. Geol. 1993, 15, 1293-1301. [CrossRef]

26. Echtler, H.; Malavieille, J. Extensional tectonics, basement uplift and Stephano-Permian collapse basin in a late Variscan metamorphic core complex (Montagne Noire, Southern Massif Central). Tectonophysics 1990, 177, 125-138. [CrossRef]

27. Ledru, P.; Courrioux, G.; Dallain, C.; Lardeaux, J.M.; Montel, J.M.; Vanderhaeghe, O.; Vitel, G. The Velay dome (French Massif Central): Melt generation and granite emplacement during orogenic evolution. Tectonophysics 2001, 342, 207-237. [CrossRef]

28. Faure, M.; Pons, J. Crustal thinning recorded by the shape of the Namurian-Westphalian leucogranite in the Variscan belt of the northwest Massif Central, France. Geology 1991, 19, 730-733. [CrossRef]

29. Cuney, M.; Alexandrov, P.; de Veslud, C.L.C.; Cheilletz, A.; Raimbault, L.; Ruffet, G.; Scaillet, S. The timing of W-Sn-rare metals mineral deposit formation in the Western Variscan chain in their orogenic setting: The case of the Limousin area (Massif Central, France). Geol. Soc. Lond. Spec. Publ. 2002, 204, 213-228. [CrossRef]

30. Pin, C.; Paquette, J.L. Sr-Nd isotope and trace element evidence for a Late Devonian active margin in northern Massif-Central (France). Geodin. Acta 2002, 15, 63-77. [CrossRef] 
31. Didier, A.; Bosse, V.; Boulvais, P.; Bouloton, J.; Paquette, J.L.; Montel, J.M.; Devidal, J.L. Disturbance versus preservation of $\mathrm{U}-\mathrm{Th}-\mathrm{Pb}$ ages in monazite during fluid-rock interaction: Textural, chemical and isotopic in situ study in microgranites (Velay Dome, France). Contrib. Miner. Petrol. 2013, 165, 1051-1072. [CrossRef]

32. Moyen, J.F.; Laurent, O.; Chelle-Michou, C.; Couzinié, S.; Vanderhaeghe, O.; Zeh, A.; Gardien, V. Collision vs. subduction-related magmatism: Two contrasting ways of granite formation and implications for crustal growth. Lithos 2017, 277, 154-177. [CrossRef]

33. Laurent, O.; Couzinié, S.; Zeh, A.; Vanderhaeghe, O.; Moyen, J.F.; Villaros, A.; Chelle-Michou, C. Protracted, coeval crust and mantle melting during Variscan late-orogenic evolution: U-Pb dating in the eastern French Massif Central. Int. J. Earth Sci. 2017, 106, 421-451. [CrossRef]

34. Vanderhaeghe, O.; Oscar, L.; Gardien, V.; Moyen, J.F.; Gébelin, A.; Chelle-Michou, C.; Bellanger, M. Flow of partially molten crust controlling construction, growth and collapse of the Variscan orogenic belt: 1 the geologic record of the French Massif Central. Bull. Société Géologique Fr. 2020, 191, 25. [CrossRef]

35. Monnier, L.; Salvi, S.; Jourdan, V.; Sall, S.; Bailly, L.; Melleton, J.; Béziat, D. Contrasting fluid behavior during two styles of greisen alteration leading to distinct wolframite mineralizations: The Echassières district (Massif Central, France). Ore Geol. Rev. 2020, 124, 103648. [CrossRef]

36. Schulz, B. EMP-monazite age controls on PT paths of garnet metapelites in the Variscan inverted metamorphic sequence of La Sioule, French Massif Central. Bull. Société Géologique Fr. 2009, 180, 271-282. [CrossRef]

37. Pin, C. Sr-Nd isotopic study of igneous and metasedimentary enclaves in some Hercynian granitoids from the Massif Central, France. Dev. Petrol. 1991, 13, 333-343.

38. Faure, M.; Monié, P.; Pin, C.; Maluski, H.; Leloix, C. Late Visean thermal event in the northern part of the French Massif Central: New $40 \mathrm{Ar} / 39 \mathrm{Ar}$ and Rb-Sr isotopic constraints on the Hercynian syn-orogenic extension. Int. J. Earth Sci. 2002, 91, 53-75. [CrossRef]

39. Duthou, J.L.; Pin, C. Etude isotopique Rb/Sr de l'apex granitique d'Echassières. Géol. Fr. 1987, 2, $63-67$.

40. Cheilletz, A.; Archibald, D.A.; Cuney, M.; Charoy, B. Ages 40Ar/39Ar du leucogranite à topaze-lépidolite de Beauvoir et des pegmatites sodolithiques de Chédeville (Nord du Massif Central, France). Signification pétrologique et géodynamique. Comptes Rendus Acad. Sci. 1992, 315, 329-336.

41. Melleton, J.; Gloaguen, E.; Frei, D. Rare-Elements (Li-Be-Ta-Sn-Nb) Magmatism in the European Variscan Belt: A Review. In Proceedings of the 13th Biennial SGA Meeting, Nancy, France, 24-27 August 2015; pp. 24-27.

42. Thiéry, V.; Rolin, P.; Marquer, D.; Cocherie, A.; Fanning, C.M.; Rossi, P. Visean sinistral wrench faulting along the Sillon Houiller in the French Massif Central: Late Variscan tectonic implications. Bull. Société Géologique Fr. 2009, 180, 513-528. [CrossRef]

43. Aubert, G. Les Coupoles Granitiques de Montebras et d'Échassières: (Massif Central Français) et la Genèse de Leurs Minéralisations en Etain, Lithium, Tungstène et Béryllium; BRGM Press: Orléans, France, 1969; Volume 46, pp. 1-349.

44. Monnier, L.; Salvi, S.; Melleton, J.; Bailly, L.; Béziat, D.; de Parseval, P.; Lach, P. Multiple Generations of Wolframite Mineralization in the Echassières District (Massif Central, France). Minerals 2019, 9, 637. [CrossRef]

45. Monnier, L.; Lach, P.; Salvi, S.; Melleton, J.; Bailly, L.; Beziat, D.; Gouy, S. Quartz trace-element composition by LA-ICP-MS as proxy for granite differentiation, hydrothermal episodes, and related mineralization: The Beauvoir Granite (Echassières district), France. Lithos 2018, 320, 355-377. [CrossRef]

46. Cuney, M.; Marignac, C.; Weisbrod, A. The Beauvoir topaz-lepidolite albite granite (Massif Central, France); the disseminated magmatic Sn-Li-Ta-Nb-Be mineralization. Econ. Geol. 1992, 87, 1766-1794. [CrossRef]

47. Béziat, P.; Coulomb, J.J.; Gentilhomme, P.; de Gramont, X. Les gisements de tungstène en France, situation en 1990. In Open Report BRGM/RR-37812-FR; BRGM Editions; BRGM Press: Orléans, France, 1990; pp. 1-107.

48. Monnier, L.; Salvi, S.; Pochon, A.; Melleton, J.; Béziat, D.; Lach, P.; Bailly, L. Antimony in quartz as a vector to mineralization: A statistical approach from five Variscan Sb occurrences (France). J. Geochem. Expl. 2021, 221, 106705. [CrossRef]

49. Gunther, D.; Heinrich, C.A. Enhanced sensitivity in LA-ICP-MS using helium-argon mixtures as aerosol carrier. J. Anal. At. Spectrom. 1999, 14, 1369-1374. [CrossRef]

50. Luvizotto, G.L.; Zack, T.; Meyer, H.P.; Ludwig, T.; Triebold, S.; Kronz, A.; von Eynatten, H. Rutile crystals as potential trace element and isotope mineral standards for microanalysis. Chem. Geol. 2009, 261, 346-369. [CrossRef]

51. Schulz, B.; Brätz, H.; Bombach, K.; Krenn, E. In-situ Th-Pb dating of monazite by $266 \mathrm{~nm}$ laser ablation and ICP-MS with a single collector, and its control by EMP analysis. Z. Angew. Geol. 2007, 35, 377-392.

52. Tomascak, P.B.; Krogstad, E.J.; Walker, R.J. U-Pb monazite geochronology of granitic rocks from Maine: Implications for late Paleozoic tectonics in the Northern Appalachians. J. Geol. 1996, 104, 185-195. [CrossRef]

53. Knoper, M. The Steenkampskraal monazite vein: A subhorizontal stretching shear zone indicating extensional collapse of Namaqualand at 1033 Ma? J. Afric. Earth Sci. 2000, 31, 38.

54. van Achterbergh, E.; Ryan, C.; Jackson, S.; Griffin, W.L. Appendix 3 Data Reduction Software for La-Icp-Ms. In Laser-AblationICPMS in the Earth Sciences; Sylvester, P., Ed.; Mineralogical Association of Canada: Quebec City, QC, Canada, 2001; pp. 239-243.

55. Ludwig, K.R. Isoplot 3.6; A geochronology toolkit for Microsoft Excel; Berkeley Geochronology Center: Berkeley, CA, USA, 2008; pp. 1-77.

56. van Hinsberg, V.J.; Schumacher, J.C. Tourmaline as a petrogenetic indicator mineral in the Haut-Allier metamorphic suite, Massif Central, France. Can. Mineral. 2011, 49, 177-194. [CrossRef] 
57. Harlaux, M.; Romer, R.L.; Mercadier, J.; Morlot, C.; Marignac, C.; Cuney, M. 40 Ma of hydrothermal W mineralization during the Variscan orogenic evolution of the French Massif Central revealed by U-Pb dating of wolframite. Miner. Depos. 2018, 53, 21-51. [CrossRef]

58. Carocci, E.; Marignac, C.; Cathelineau, M.; Truche, L.; Lecomte, A.; Pinto, F. Rutile from Panasqueira (Central Portugal): An excellent pathfinder for wolframite deposition. Minerals 2019, 9, 9. [CrossRef]

59. Lang, J.R. An exploration model for intrusion-related gold systems. Soc. Econ. Geol. Newsl. 2000, 40, 6-15.

60. Pirajno, F. Intrusion-Related hydrothermal mineral systems. In Hydrothermal Processes and Mineral Systems; Springer Science \& Business Media: Berlin, Germany, 2008; pp. 205-354.

61. Peiffer, M.T. La signification de la ligne tonalitique du Limousin. Son implication dans la structuration varisque du Massif Central français. Comptes Rendus Acad. Sci. 1986, 303, 305-310.

62. Cuney, M.; Stussi, J.M.; Brouand, M.; Dautel, D.; Michard, A. Géochimie et géochronologie U/Pb des diorites quartziques du Tallud et de Moncoutant: Nouveaux arguments pour une extension de la Ligne Tonalitique Limousine en Vendée. Comptes Rendus Acad. Sci. 1993, 316, 1383-1390.

63. Shaw, A.; Downes, H.; Thirlwall, M.F. The quartz-diorites of Limousin: Elemental and isotopic evidence for Devono-Carboniferous subduction in the Hercynian belt of the French Massif Central. Chem. Geol. 1993, 107, 1-18. [CrossRef]

64. Finger, F.; Roberts, M.P.; Haunschmid, B.; Schermaier, A.; Steyrer, H.P. Variscan granitoids of central Europe: Their typology, potential sources and tectonothermal relations. Miner. Petrol. 1997, 61, 67-96. [CrossRef]

65. Mlynarczyk, M.S.; Williams-Jones, A.E. The role of collisional tectonics in the metallogeny of the Central Andean tin belt. Earth Planet Sci. Let. 2005, 240, 656-667. [CrossRef]

66. Gemmrich, L.; Torró, L.; Melgarejo, J.C.; Laurent, O.; Vallance, J.; Chelle-Michou, C.; Sempere, T.P. Trace element composition and $\mathrm{U}-\mathrm{Pb}$ ages of cassiterite from the Bolivian tin belt. Miner. Depos. 2021, 1-30. [CrossRef]

67. Sinclair, W.D.; Kooiman, G.J.; Martin, D.A. Geological setting of granites and related tin deposits in the North Zone, Mount Pleasant, New Brunswick. Geol. Surv. Can. 1988, Part B, 201-208.

68. Samson, I.M. Fluid evolution and mineralization in a subvolcanic granite stock; the Mount Pleasant W-Mo-Sn deposits, New Brunswick, Canada. Econ. Geol. 1990, 85, 145-163. [CrossRef]

69. Mac Cutcheon, S.R.; Anderson, H.E.; Robinson, P.T. Stratigraphy and eruptive history of the Late Devonian Mount Pleasant caldera complex, Canadian Appalachians. Geol. Mag. 1997, 134, 17-36. [CrossRef]

70. MacLellan, H.E.; Taylor, R.P. Geology and geochemistry of the Burnthill Granite and related W-Sn-Mo-F mineral deposits, central New Brunswick. Can. J. Earth Sci. 1989, 26, 499-514. [CrossRef]

71. Thorne, K.G.; Fyffe, L.R.; Creaser, R.A. Re-Os geochronological constraints on the W-Mo mineralizing event in the Mount Pleasant Caldera Complex: Implications for the timing of subvolcanic magmatism and caldera development. Atl. Geol. 2013, 49, 131-151. [CrossRef]

72. Mohammadi, N.; Lentz, D.R.; FMCarlane, C.R.; Cousens, B. Geochemistry of the highly evolved Sn-W-Mo-bearing Mount Douglas Granite, New Brunswick, Canada: Implications for origin and mineralization. Ore Geol. Rev. 2020, 117, 103266. [CrossRef]

73. Charnley, B.; Lentz, D.R.; McFarlane, C.R. Hydrothermal monazite and xenotime related to granites associated with the North Zone Mount Pleasant Sn-Zn-Cu-In (\& W) deposits, NB, Canada: Preliminary studies. In Proceedings of the 14th Biennial SGA Meeting, Québec City, QC, Canada, 20-23 August 2017; pp. 369-372.

74. Mohammadi, N.; Mc Farlane, C.R.; Lentz, D.R.; Thorne, K.G. Timing of magmatic crystallization and Sn-W-Mo greisen vein formation within the Mount Douglas Granite, New Brunswick, Canada. Can. J. Earth Sci. 2020, 57, 814-839. [CrossRef]

75. Arthaud, F.; Matte, P. Les décrochements tardi-hercyniens du sud-ouest de l'Europe. Géométrie et essai de reconstitution des conditions de la déformation. Tectonophysics 1975, 25, 139-171. [CrossRef]

76. Gébelin, A.; Roger, F.; Brunel, M. Syntectonic crustal melting and high-grade metamorphism in a transpressional regime, Variscan Massif Central, France. Tectonophysics 2009, 477, 229-243. [CrossRef]

77. Burg, J.P.; van den Driessche, J.; Brun, J.P. Syn-to post-thickening extension in the Variscan Belt of Western Europe: Modes and structural consequences. Géol. Fr. 1994, 3, 33-51.

78. Gardien, V.; Vanderhaeghe, O.; Arnaud, N.; Cocherie, A.; Grange, M.; Lécuyer, C. Thermal maturation and exhumation of a middle orogenic crust in the Livradois area (French Massif Central). Bull. Société Géologique Fr. 2011, 182, 5-24. [CrossRef]

79. Bruguier, O.; Becq-Giraudon, J.F.; Bosch, D.; Lancelot, J.R. Late Visean hidden basins in the internal zones of the Variscan belt: $\mathrm{U}-\mathrm{Pb}$ zircon evidence from the French Massif Central. Geology 1998, 26, 627-630. [CrossRef]

80. Vanderhaeghe, O.; Teyssier, C. Partial melting and flow of orogens. Tectonophysics 2001, 342, 451-472. [CrossRef]

81. Cambeses, A.; Molina, J.F.; Morales, I.; Lázaro, C.; Moreno, J.A.; Montero, P.; Bea, F. Compositional Evolution of the Variscan Intra-Orogenic Extensional Magmatism in the Valencia del Ventoso Plutonic Complex, Ossa-Morena Zone (SW Iberia): A View from Amphibole Compositional Relationships. Minerals 2021, 11, 431. [CrossRef]

82. Zhang, R.; Lehmann, B.; Seltmann, R.; Sun, W.; Li, C. Cassiterite U-Pb geochronology constrains magmatic-hydrothermal evolution in complex evolved granite systems: The classic Erzgebirge tin province (Saxony and Bohemia). Geology 2017, 45, 1095-1098. [CrossRef]

83. Burisch, M.; Gerdes, A.; Meinert, L.D.; Albert, R.; Seifert, T.; Gutzmer, J. The essence of time-fertile skarn formation in the Variscan Orogenic Belt. Earth Planet Sci. Lett. 2019, 519, 165-170. [CrossRef] 
84. Friedl, G.; Cooke, R.A.; Finger, F.; McNaughton, N.J.; Fletcher, I.R. Timing of Variscan HP-HT metamorphism in the Moldanubian Zone of the Bohemian Massif: U-Pb SHRIMP dating on multiply zoned zircons from a granulite from the Dunkelsteiner Wald Massif, Lower Austria. Miner. Petrol. 2011, 102, 63-75. [CrossRef]

85. Wang, R.; Wu, F.; Xie, L.; Liu, X.; Wang, J.; Yang, L.; Liu, C. A preliminary study of rare-metal mineralization in the Himalayan leucogranite belts, South Tibet. Sci. China Earth Sci. 2017, 60, 1655-1663. [CrossRef]

86. Li, G.M.; Zhang, L.K.; Jiao, Y.J.; Xia, X.B.; Dong, S.L.; Fu, J.G.; Huang, Y. First discovery and implications of Cuonadong superlarge Be-W-Sn polymetallic deposit in Himalayan metallogenic belt, southern Tibet. Miner. Dep. 2017, 36, 1003-1008.

87. Xie, L.; Tao, X.; Wang, R.; Wu, F.; Liu, C.; Liu, X.; Zhang, R. Highly fractionated leucogranites in the eastern Himalayan Cuonadong dome and related magmatic Be-Nb-Ta and hydrothermal Be-W-Sn mineralization. Lithos 2020, 354, 105286. [CrossRef]

88. Kempe, U.; Bombach, K.; Matukov, D.; Schlothauer, T.; Hutschenreuter, J.; Wolf, D.; Sergeev, S. Pb/Pb and U/Pb zircon dating of subvolcanic rhyolite as a time marker for Hercynian granite magmatism and Sn mineralisation in the Eibenstock granite, Erzgebirge, Germany: Considering effects of zircon alteration. Miner. Depos. 2004, 39, 646-669. [CrossRef]

89. Mikulski, S.Z.; Williams, I.S.; Stein, H.J.; Wierchowiec, J. Zircon U-Pb Dating of Magmatism and Mineralizing Hydrothermal Activity in the Variscan Karkonosze Massif and Its Eastern Metamorphic Cover (SW Poland). Minerals 2020, 10, 787. [CrossRef]

90. Hoffmann, U.; Breitkreuz, C.; Breiter, K.; Sergeev, S.; Stanek, K.; Tichomirowa, M. Carboniferous-Permian volcanic evolution in Central Europe- $\mathrm{U} / \mathrm{Pb}$ ages of volcanic rocks in Saxony (Germany) and northern Bohemia (Czech Republic). Int. J. Earth Sci. 2013, 102, 73-99. [CrossRef]

91. Noronha, F.; Doria, A.; Dubessy, J.; Charoy, B. Characterization and timing of the different types of fluids present in the barren and ore-veins of the W-Sn deposit of Panasqueira, Central Portugal. Miner. Depos. 1992, 27, 72-79. [CrossRef]

92. Chicharro, E.; Martín-Crespo, T.; Gómez-Ortiz, D.; López-García, J.Á.; Oyarzun, R.; Villaseca, C. Geology and gravity modeling of the Logrosán Sn-(W) ore deposits (Central Iberian Zone, Spain). Ore Geol. Rev. 2015, 65, 294-307. [CrossRef]

93. Chicharro, E.; Boiron, M.C.; López-García, J.Á.; Barfod, D.N.; Villaseca, C. Origin, ore forming fluid evolution and timing of the Logrosán Sn-(W) ore deposits (Central Iberian Zone, Spain). Ore Geol. Rev. 2016, 72, 896-913. [CrossRef]

94. Yang, M.; Yang, Y.H.; Wu, S.T.; Romer, R.L.; Che, X.D.; Zhao, Z.F.; Zhang, Y. Accurate and precise in situ U-Pb isotope dating of wolframite series minerals via LA-SF-ICP-MS. J. Analyt. At. Spectro. 2020, 35, 2191-2203. [CrossRef]

95. Lehmann, B.; Zoheir, B.A.; Neymark, L.A.; Zeh, A.; Emam, A.; Radwan, A.M.; Moscati, R.J. Monazite and cassiterite UPb dating of the Abu Dabbab rare-metal granite, Egypt: Late Cryogenian metalliferous granite magmatism in the Arabian-Nubian Shield. Gond. Res. 2020, 84, 71-80. [CrossRef]

96. Zoheir, B.; Zeh, A.; El-Bialy, M.; Ragab, A.; Deshesh, F.; Steele-MacInnis, M. Hybrid granite magmatism during orogenic collapse in the Eastern Desert of Egypt: Inferences from whole-rock geochemistry and zircon $\mathrm{U}-\mathrm{Pb}-\mathrm{Hf}$ isotopes. Precambrian Res. 2021, 354, 106044. [CrossRef]

97. Michaud, J.; Pichavant, M. The H/F ratio as an indicator of contrasted wolframite deposition mechanisms. Ore Geol. Rev. 2019, 104, 266-272. [CrossRef]

98. Mikulski, S.; Williams, I.S.; Markowiak, M. Carboniferous-Permian magmatism and Mo-Cu (-W) mineralization in the contact zone between the Małopolska and Upper Silesia Blocks (S Poland)-an echo of Baltica-Gondwana collision. Int. J. Earth Sci. 2019, 108, 1467-1492. [CrossRef]

99. Timmerman, M.J. Timing, geodynamic setting and character of Permo-Carboniferous magmatism in the foreland of the Variscan Orogen, NW Europe. Geol. Soc. Spec. Publ. 2004, 223, 41-74. [CrossRef] 